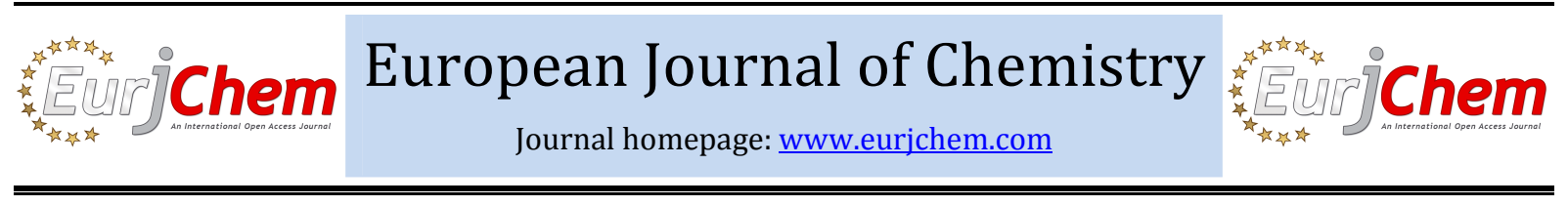

\title{
Synthesis of new derivatives of 2-chloro-3-formyl-1,8-naphthyridine
}

\author{
Mohanad Yakdhan Saleh a,* and Ala Ismael Ayoub b \\ a Department of Chemistry, College of Education for Pure Sciences, University of Mosul, 41002, Mosul, Iraq \\ b Department of Chemistry, College of Sciences, University of Mosul, 41002, Mosul, Iraq \\ *Corresponding author at: Department of Chemistry, College of Education for Pure Sciences, University of Mosul, 41002, Mosul, Iraq. \\ Tel.: +964.770.1885033. Fax: +964.770.1885033.E-mail address: mohanadalallaf@yahoo.com (M.Y. Saleh).
}

\section{ARTICLE INFORMATION}

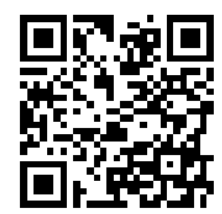

DOI: 10.5155/eurjchem.5.3.475-480.1050

Received: 13 March 2014

Received in revised form: 24 April 2014

Accepted: 04 May 2014

Online: 30 September 2014

\section{KEYWORDS}

Triazol

Thiadizol

Azetidine

Oxadiazol

Naphthyridine

Vilsmeier-Haack

\section{Introduction}

Naphthyridine or naphthyridone derivatives are great important because the 1,8-naphthyridine skeleton is present in many compounds that have been isolated from natural substance, with various biological activities. Gemifloxacin is an antimicrobial which have naphthyridine skeleton [1]. It is known that substituted 1,8-naphthayridine series are potential drug for local anesthesia [2] and 1-2(2-florobenzyl-3-(2-tolyle)1,8-naphthyridine-2 $(H)$-one is used for treatment of memory disease [3]. Recently, quinolines and 1,8-naphthyridine are being exploited in cancer chemotherapy [4]. Various 1,8naphthyridine derivatives have been reported to possess promising biological activities such as antibacterial [5], antimalarial [6] , anti-tumor [7], anti-inflammatory [8], and antihypertensive activities [9]. There are many methods used to prepare various types of 1,8-naphthyridine system involves consideration of 2-aminopyridine derivatives with carbonyl compounds containing an activated methylene group $[7,10,11]$ or with $\beta$-ketoesters [12] or condensation of ethanolic 2amino-3-formyl pyridine in the presence of piperidine base with active methylene compounds aldehydes, acyclic and cyclic ketone or diketones [13-15]. The Vilsmeier-Haack reagent has been proved to be averstile reagent capable of executing a large variety of synthetic transformations [16]. It finds applications in formylation [17], cyclohaloaddition [18], cyclisation [19] and ring annulations [20].
The aim of this work was to synthesized new 1,8naphthyridine derivatives. In addition, we have obtained naphthyridine based azitidinone (8-10) and oxadiazole, thiadiazole, triazole $(15,16$ and 17) and studies the biological activity of some compounds $(\mathbf{1 6}, 17$ and $\mathbf{1 8})$.

\section{Experimental}

\subsection{Instrumentation}

Melting point were recorded on electro-thermal CIA9300 melting point apparatus and are uncorrected, ${ }^{1} \mathrm{H}$ NMR spectra were recorded on nucleic magnetic resinous model Ultra Shield $400 \mathrm{MHz}$, Bruker Co., Germany, using TMS as internal reference and DMSO- $d_{6}$ as solvent . IR spectra were recorded on Infrared Spectrophotometer Model Tensor 27, Bruker Co., Germany, by using $\mathrm{KBr}$ discs.

\subsection{Synthesis of 2-chloro-3-formyl-1,8-naphthyridine (1)}

To solution of $N$-(pyridine-2-yl)acetamide ( 5 mmoles) in dry DMF $(15 \mathrm{~mL})$, at $\left(0-5^{\circ} \mathrm{C}\right)$ with stirring $\mathrm{POCl}_{3}$ (60 mmoles) was added drop wise. The reaction mixture stirred at (80-90 ${ }^{\circ} \mathrm{C}$ ) for $15 \mathrm{hr}$. The reaction mixture was poured into crushed ice, stirred for $30 \mathrm{~min}$ and the resulting solid filtered, washed well with water and dried and re-crystallized from ethyl alcohol to give pure compound $\mathbf{1}$ (Scheme 1 ). 


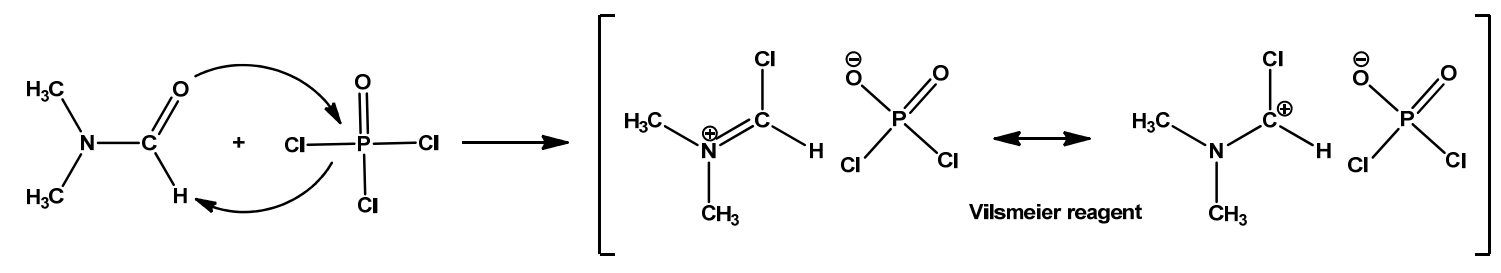<smiles>CC(=O)Nc1ccccn1</smiles>

Yield: 63\%. Color: Pale yellow. M.p.: $165-157{ }^{\circ} \mathrm{C}$. FT-IR $\left(\mathrm{KBr}, v, \mathrm{~cm}^{-1}\right): 3055(\mathrm{ArC}-\mathrm{H}), 2780(\mathrm{C}-\mathrm{H}), 1720(\mathrm{C}=\mathrm{O}), 1590$ $(\mathrm{C}=\mathrm{N}), 775(\mathrm{C}-\mathrm{Cl}) .{ }^{1} \mathrm{H}$ NMR $\left(400 \mathrm{MHz}, \mathrm{DMSO}-d_{6}, \delta, \mathrm{ppm}\right): 7.25(\mathrm{t}$, $1 \mathrm{H}, \mathrm{C}-6-\mathrm{H}), 7.44(\mathrm{~d}, 1 \mathrm{H}, \mathrm{C}-5-\mathrm{H}), 7.85(\mathrm{~s}, 1 \mathrm{H}, \mathrm{C}-4-\mathrm{H}), 8.44(\mathrm{~m}, 1 \mathrm{H}$, C-7-H), 9.85 (s, 1H, CHO).

\subsection{Synthesis of 2-mercapto-3-formyl-1,8-naphthyridine (2)}

To a solution of compound $\mathbf{1}$ (1 mmole) in ( $5 \mathrm{~mL}$ ) dry DMF, (1.5 mmole) of sodium sulphide was added and then the reaction mixture was stirred for $4 \mathrm{hr}$ at room temperature. The reaction mixture was poured into $20 \mathrm{~mL}$ of crushed ice and acidified with acetic acid. The solid thus obtained was filtered and re-crystallized from ethyl alcohol to give pure compound $\mathbf{2}$ (Scheme 2). Yield: 67\%. Color: Yellow powder. M.p.: 220-223 ${ }^{\circ} \mathrm{C}$. FT-IR (KBr, v, cm $\left.{ }^{-1}\right)$ : 3020 (ArC-H), $2792(\mathrm{C}-\mathrm{H}), 1690(\mathrm{C}=\mathrm{O})$, $1595(\mathrm{C}=\mathrm{N}), 1050(\mathrm{C}=\mathrm{S}) .{ }^{1} \mathrm{H}$ NMR $\left(400 \mathrm{MHz}, \mathrm{DMSO}-d_{6}, \delta, \mathrm{ppm}\right)$ : $6.02(\mathrm{~s}, 1 \mathrm{H}, \mathrm{S}-\mathrm{H}) 7.43(\mathrm{t}, 1 \mathrm{H}, \mathrm{C}-6-\mathrm{H}), 7.75$ (d, 1H, C-5-H), 8.16 (s, $1 \mathrm{H}, \mathrm{C}-4-\mathrm{H}), 8.60(\mathrm{~m}, 1 \mathrm{H}, \mathrm{C}-7-\mathrm{H}), 9.88$ (s, 1H, CHO).

\subsection{Synthesis of thioethers 3-formyl-2-methylthio-1,8- naphthyridine (3) and 3-formyl-2-benzylthio-1,8- naphthyridine (4)}

To a solution of compound 1 (1 mmole) in $5 \mathrm{~mL}$ dry DMF, sodium sulphide ( 1.5 mmole) was added and stirred for $4 \mathrm{hr}$ at room temperature, then the corresponding halo compound (methyl iodide or benzyl chloride) was added and stirred for another $1 \mathrm{hr}$ and poured into ice-cooled water. The precipitate obtained was filtered dried and re-crystallized from ethanol to give pure compound $\mathbf{3}$ and $\mathbf{4}$ (Scheme 2 ).

3-Formyl-2-methylthio-1,8-naphthyridine (3): Yield: 81\%. Color: Yellow. M.p.: $105-108^{\circ} \mathrm{C}$. FT-IR $\left(\mathrm{KBr}, v, \mathrm{~cm}^{-1}\right): 3050$ (ArC$\mathrm{H}), 2775(\mathrm{C}-\mathrm{H}), 1687(\mathrm{C}=\mathrm{O}), 1590(\mathrm{C}=\mathrm{N}) .{ }^{1} \mathrm{H}$ NMR $(400 \mathrm{MHz}$, DMSO- $\left.d_{6}, \delta, \mathrm{ppm}\right): 2.86\left(\mathrm{~s}, 3 \mathrm{H}, \mathrm{SCH}_{3}\right), 7.44(\mathrm{t}, 1 \mathrm{H}, \mathrm{C}-6-\mathrm{H}), 7.75$ (d, 1H, C-5-H), 8.18 (s, 1H, C-4-H), 8.64 (m, 1H, C-7-H), 9.86 (s, $1 \mathrm{H}, \mathrm{CHO})$.

3-Formyl-2-benzylthio-1,8-naphthyridine (4): Yield: 83\%. Color: Brown powder. M.p.: $111-113{ }^{\circ} \mathrm{C}$. FT-IR $\left(\mathrm{KBr}, v, \mathrm{~cm}^{-1}\right)$ : 3085 (ArC-H), 2780 (C-H), 1680 (C=0), 1585 (C=N). ${ }^{1} \mathrm{H}$ NMR (400 MHz, DMSO- $\left.d_{6}, \delta, \mathrm{ppm}\right): 4.6\left(\mathrm{~s}, 2 \mathrm{H}, \mathrm{SCH}_{2}\right), 7.1-7.4(\mathrm{~m}, 5 \mathrm{H}$ Ar-H), 7.48 (t, 1H, C-6-H), 7.75 (d, 1H, C-5-H), 8.16 (s, 1H, C-4$\mathrm{H}), 8.64(\mathrm{~m}, 1 \mathrm{H}, \mathrm{C}-7-\mathrm{H}), 9.86(\mathrm{~s}, 1 \mathrm{H}, \mathrm{CHO})$.

\subsection{Synthesis of 2-chloro-1,8-naphthyridine-3-carbaldehyde (phenyl hydrazone) (5)}

To a solution of compound $\mathbf{1}$ (1 mmole) in ethanol $(5 \mathrm{~mL})$ was added with stirring phenyl hydrazine $(2 \mathrm{mmole})$, and the mixture was refluxed for $4 \mathrm{hr}$. On cooling, the yellow precipitate was formed, filtered off, washed with ethanol and cold water, dried and re-crystallized from ethanol to give pure compound 5 (Scheme 2). Yield: 76\%. Color: Yellow. M.p.: 223$225^{\circ} \mathrm{C}$. FT-IR (KBr, v, cm-1): $3340(\mathrm{~N}-\mathrm{H}), 3045$ (ArC-H), 1625 $(\mathrm{C}=\mathrm{N}), 745(\mathrm{C}-\mathrm{Cl}) .{ }^{1} \mathrm{H}$ NMR $\left(400 \mathrm{MHz}, \mathrm{DMSO}-d_{6}, \delta, \mathrm{ppm}\right): 6.23(\mathrm{~s}$, $1 \mathrm{H}, \mathrm{NH}), 7.11-7.42(5 \mathrm{H}, \mathrm{m}, \mathrm{Ar}-\mathrm{H}), 7.48(\mathrm{t}, 1 \mathrm{H}, \mathrm{C}-6-\mathrm{H}), 7.83(\mathrm{~d}$, $1 \mathrm{H}, \mathrm{C}-5-\mathrm{H}), 9.14(\mathrm{~s}, 1 \mathrm{H}, \mathrm{CH}), 8.60(\mathrm{~s}, 1 \mathrm{H}, \mathrm{C}-4-\mathrm{H}), 8.93(\mathrm{~m}, 1 \mathrm{H}, \mathrm{C}-$ 7-H).

2.6. Synthesis of 2-chloro-1,8-naphthyridine-3-carbaldehyde (4-nitro phenyl hydrazone) (6)

To a solution of compound $\mathbf{1}(1 \mathrm{mmole})$ in ethanol $(5 \mathrm{~mL})$ was added with stirring 4-nitro phenyl hydrazine $(2 \mathrm{mmole})$, and refluxed for $4 \mathrm{hr}$ on cooling the precipitate was formed dried and re-crystallized from ethanol to give pure compound 6 (Scheme 2). Yield: 85\%. Color: Brown. M.p.: 228-230 ${ }^{\circ} \mathrm{C}$. FT-IR $\left(\mathrm{KBr}, v, \mathrm{~cm}^{-1}\right): 3335(\mathrm{~N}-\mathrm{H}), 3055(\mathrm{ArC}-\mathrm{H}), 1605(\mathrm{C}=\mathrm{N}), 1535$, 1310 ( $\left.\mathrm{NO}_{2 \mathrm{Asym}, \mathrm{Sym}}\right), 740(\mathrm{C}-\mathrm{Cl}) .{ }^{1} \mathrm{H}$ NMR $\left(400 \mathrm{MHz}, \mathrm{DMSO}-d_{6}, \delta\right.$, ppm): $6.23(\mathrm{~s}, 1 \mathrm{H}, \mathrm{NH}), 7.11-7.41(\mathrm{~m}, 4 \mathrm{H}, \mathrm{Ar}-\mathrm{H}), 7.48(\mathrm{t}, 1 \mathrm{H}, \mathrm{C}-6-$ $\mathrm{H}), 7.81(\mathrm{~d}, 1 \mathrm{H}, \mathrm{C}-5-\mathrm{H}), 9.14(\mathrm{~s}, 1 \mathrm{H},-\mathrm{CH}), 8.61(\mathrm{~s}, 1 \mathrm{H}, \mathrm{C}-4-\mathrm{H})$, $8.90(\mathrm{~m}, 1 \mathrm{H}, \mathrm{C}-7-\mathrm{H})$.

\subsection{Synthesis of 2-chloro-1,8-caphthyridine-3-carbaldehyde (2,4-dinitro phenyl hydrazone) (7)}

To a solution of compound $\mathbf{1}(1 \mathrm{mmole})$ in ethanol $(5 \mathrm{~mL})$ was added with stirring 2,4-dinitro-phenyl hydrazine (2 mmole), and refluxed for $4 \mathrm{hr}$ on cooling the precipitate was formed dried and re-crystallized from ethanol to give pure compound 7 (Scheme 2). Yield: 78\%. Color: Orange. M.p.: 235$236^{\circ} \mathrm{C}$. FT-IR $\left(\mathrm{KBr}, \mathrm{v}, \mathrm{cm}^{-1}\right): 3324(\mathrm{~N}-\mathrm{H}), 3100(\mathrm{ArC}-\mathrm{H}), 1595$ $(\mathrm{C}=\mathrm{N}), 1565,1385$ ( $\mathrm{NO}_{2 \mathrm{Asym}}$, Sym $), 740(\mathrm{C}-\mathrm{Cl}) .{ }^{1} \mathrm{H}$ NMR $(400 \mathrm{MHz}$ DMSO- $\left.d_{6}, \delta, \mathrm{ppm}\right):$ 7.01-7.42 $(\mathrm{m}, 3 \mathrm{H}, \mathrm{Ar}-\mathrm{H}), 6.23(\mathrm{~s}, 1 \mathrm{H}, \mathrm{NH})$, $7.48(\mathrm{t}, 1 \mathrm{H}, \mathrm{C}-6-\mathrm{H}), 7.78(\mathrm{~d}, 1 \mathrm{H}, \mathrm{C}-5-\mathrm{H}), 9.02(\mathrm{~s}, 1 \mathrm{H}, \mathrm{CH}), 8.41(\mathrm{~s}$, 1H, C-4-H), 8.82 (m, 1H, C-7-H).

\subsection{Synthesis of 3-chloro-4-(2-chloro-1,8-naphthyridine-3-} yl)-1-(phenylamino)azetidin-2-one (8)

The compound 5 ( 0.01 mole) was dissolved in dry DMF (20 $\mathrm{mL})$ and triethylamine (0.02 mole) was added to it. Chloroacetyle chloride ( 0.02 mole) was added drop wise for a period of $30 \mathrm{~min}$. The reaction mixture was refluxed for $6 \mathrm{hr}$. then poured into crushed ice, the resulting solid was filtered washed with cold water and re-crystallized from ethyl acetate to give pure compound 8 (Scheme 2). Yield: $65 \%$. Color: Yellow. M.p.: $251-253^{\circ} \mathrm{C}$. FT-IR (KBr, v, cm-1): $3344(\mathrm{~N}-\mathrm{H}), 3025$ (ArC$\mathrm{H}), 1665(\mathrm{C}=\mathrm{O}), 1575(\mathrm{C}=\mathrm{N}), 755(\mathrm{C}-\mathrm{Cl})$. 


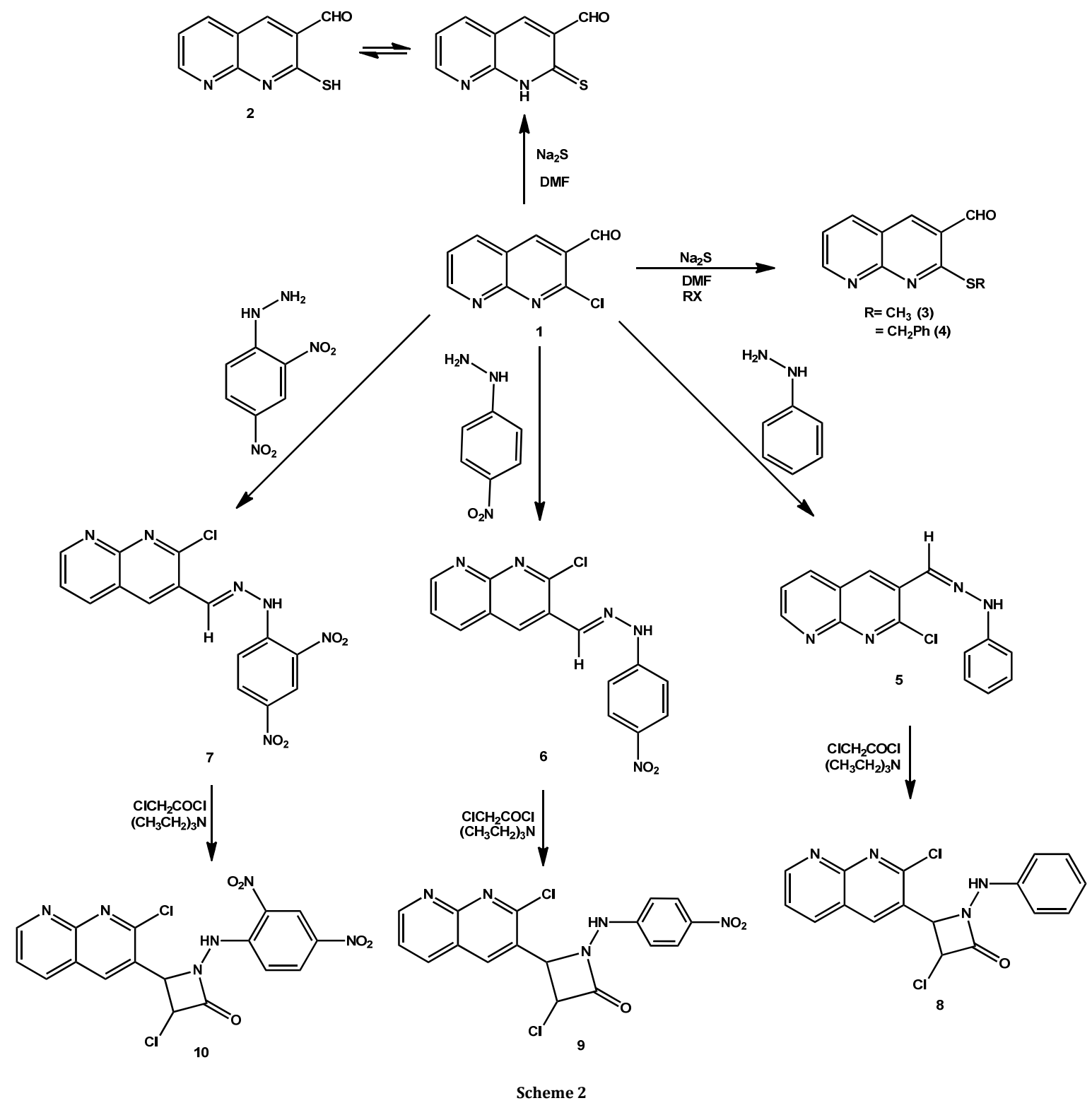

${ }^{1} \mathrm{H}$ NMR (400 MHz, DMSO- $\left.d_{6}, \delta, \mathrm{ppm}\right): 6.15(\mathrm{~s}, 1 \mathrm{H}, \mathrm{NH}), 5.82$ (d, 1H, CH-Cl), 6.95 (d, 1H, CH-N), 7.20-7.35 (m, 5H, Ar-H), 7.41 (t, 1H, C-6-H), 7.85 (d, 1H, C-5-H), 8.56 (s, 1H, C-4-H), 8.78 (m, 1H, C-7-H).

\subsection{Synthesis of 3-chloro-4-(2-chloro-1,8-naphthyridin-3yl)- 1-((4-nitrophenyl) amino)-azetidin-2-one (9)}

The compound 6 ( 0.01 mole) was dissolved in dry DMF (20 $\mathrm{mL}$ ) and triethylamine (0.02 mole) was added to it. Chloroacetyle chloride ( 0.02 mole) was added drop wise for a period of $30 \mathrm{~min}$. The reaction mixture was refluxed for $6 \mathrm{hr}$. The reaction mixture was poured into crushed ice, the resulting solid was filtered washed well with cold water and recrystallized from ethyl acetate to give pure compound 9 (Scheme 2). Yield: $63 \%$. Color: Yellow. M.p.: 236-237 ${ }^{\circ} \mathrm{C}$. FT-IR $\left(\mathrm{KBr}, v, \mathrm{~cm}^{-1}\right): 3440(\mathrm{~N}-\mathrm{H}), 3050(\mathrm{ArC}-\mathrm{H}), 1665(\mathrm{C}=0), 1545$ $(\mathrm{C}=\mathrm{N}), 1555,1370\left(\mathrm{NO}_{2 \mathrm{Asym}, \mathrm{Sym}}\right), 765(\mathrm{C}-\mathrm{Cl}) .{ }^{1} \mathrm{H}$ NMR $(400 \mathrm{MHz}$, DMSO- $\left.d_{6}, \delta, p p m\right): 5.84(\mathrm{~d}, 1 \mathrm{H}, \mathrm{CH}-\mathrm{Cl}), 6.23(\mathrm{~s}, 1 \mathrm{H}, \mathrm{NH}), 6.92(\mathrm{~m}$,
1H, CH-N), 7.15-7.33 (m, 4H, Ar-H), 7.48 (t, 1H, C-6-H), 7.80 (d, 1H, C-5-H), 8.52 (d, 1H, C-4-H), $8.72(\mathrm{~m}, 1 \mathrm{H}, \mathrm{C}-7-\mathrm{H})$.

2.10. Synthesis of 3-chloro-4-(2-chloro-1,8-naphthyridine-3yl)-1-((2,4-dinitrophenyl) amino)-azetidin-2-one (10)

The compound 7 ( 0.01 mole) was dissolved in dry DMF (20 $\mathrm{mL})$ and triethylamine $(0.02$ mole $)$ was added to it. Chloroacetyle chloride $(0.02$ mole) was added drop wise for a period of $30 \mathrm{~min}$. The reaction mixture was refluxed for $6 \mathrm{hr}$. The reaction mixture was poured into crushed ice, the resulting solid was filtered washed well with cold water and recrystallized from ethyl acetate to give pure compound $\mathbf{1 0}$ (Scheme 2). Yield: 89\%. Color: Yellow. M.p.: 222-225 ${ }^{\circ} \mathrm{C}$. FT-IR $\left(\mathrm{KBr}, v, \mathrm{~cm}^{-1}\right): 3445(\mathrm{~N}-\mathrm{H}), 3035(\mathrm{ArC}-\mathrm{H}), 1665(\mathrm{C}=\mathrm{O}), 1510$ $(\mathrm{C}=\mathrm{N}), 1565,1340\left(\mathrm{NO}_{2 \mathrm{Asym}}, \mathrm{Sym}\right), 745(\mathrm{C}-\mathrm{Cl}) .{ }^{1} \mathrm{H}$ NMR $(400 \mathrm{MHz}$ DMSO- $\left.d_{6}, \delta, \mathrm{ppm}\right): 5.88(\mathrm{~d}, 1 \mathrm{H}, \mathrm{CH}-\mathrm{Cl}), 6.04(\mathrm{~s}, 1 \mathrm{H}, \mathrm{NH}), 6.92(\mathrm{~m}$, 1H, C-7-H), 7.13-7.33 (m, 3H, Ar-H), 7.40 (t, 1H, C-6-H), 7.80 (d, $1 \mathrm{H}, \mathrm{C}-5-\mathrm{H}), 8.52$ (s, 1H, C-4-H), $8.72(\mathrm{~m}, 1 \mathrm{H}, \mathrm{C}-7-\mathrm{H})$. 


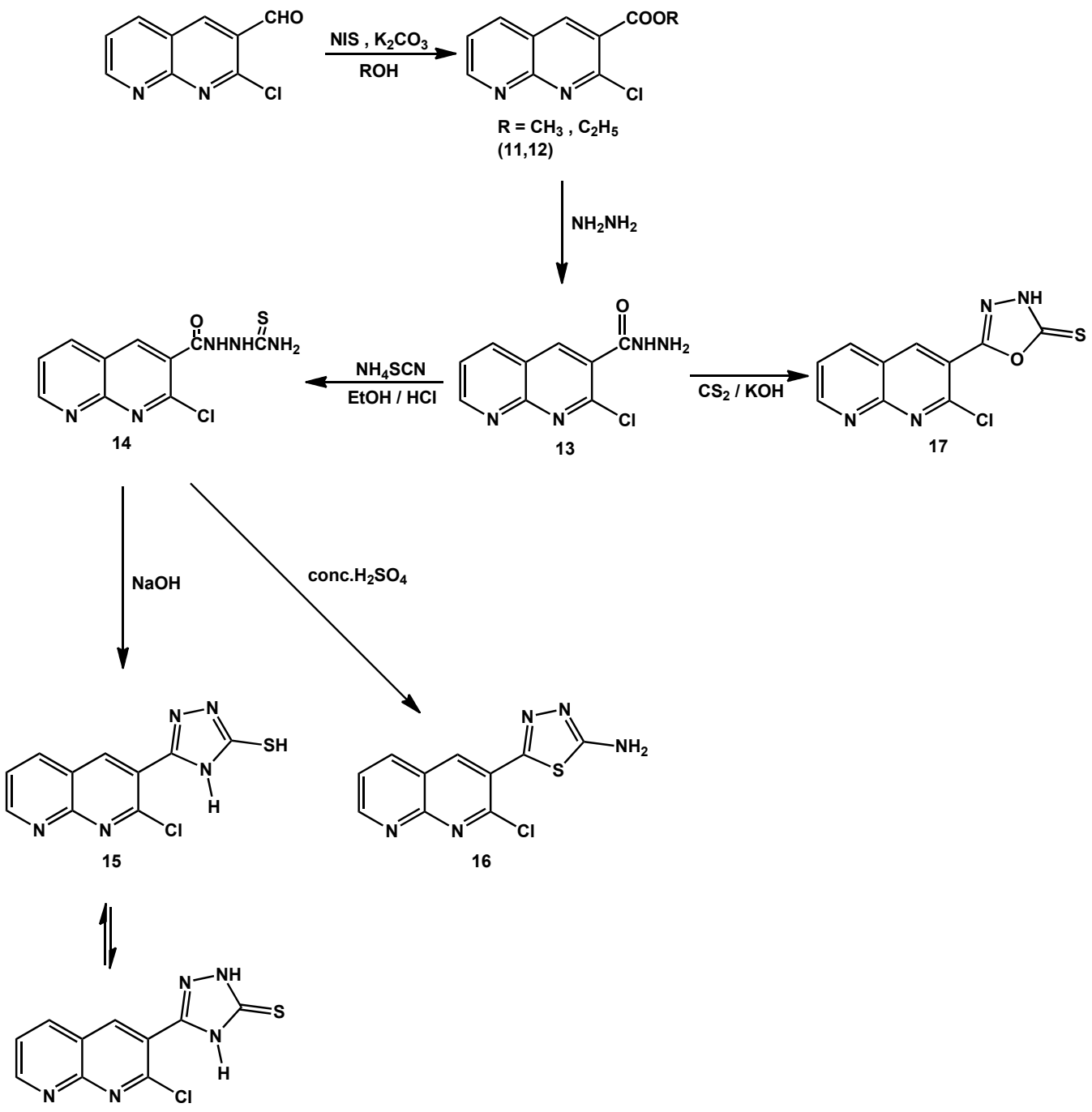

Scheme 3

2.11. Conversion to methyl and ethyl ester derivatives: Synthesis of 2-chloro-3-(methoxy or ethoxy) carbonyl-1,8naphthyridine $(11,12)$

To a solution of compound 1 ( 1 mmole) in methanol or ethanol $(10 \mathrm{~mL})$ were added NIS ( $N$-iodo succimide) $(2.5$ mmole) and potassium carbonate $(2.5 \mathrm{mmole})$. The resultant dark mixture was stirred in dark for $6 \mathrm{hr}$. The reaction mixture was then diluted with 5-6 mL of water and sodium thiosulphite $(0.5 \mathrm{~g})$ was added to destroy any remaining NIS or hypoiodite species and the solid product filtered, dried and re-crystallized from ethanol to give pure compound $\mathbf{1 1}$ and $\mathbf{1 2}$ (Scheme 3).

2-Chloro-3-methoxycarbonyl-1,8-naphthyridine (11): Yield: 81\%. Color: Pale yellow. M.p.: $82-84{ }^{\circ} \mathrm{C}$. FT-IR $\left(\mathrm{KBr}, v, \mathrm{~cm}^{-1}\right)$ : $3045(\mathrm{ArC}-\mathrm{H}), 1735(\mathrm{C}=0), 1595(\mathrm{C}=\mathrm{N}), 760(\mathrm{C}-\mathrm{Cl}) .{ }^{1} \mathrm{H}$ NMR $\left(400 \mathrm{MHz}, \mathrm{DMSO}-d_{6}, \delta, \mathrm{ppm}\right): 4.15\left(\mathrm{~s}, 3 \mathrm{H}, \mathrm{OCH}_{3}\right), 7.28(\mathrm{t}, 1 \mathrm{H}, \mathrm{C}-$ 6-H), 7.48 (d, 1H, C-5-H), 7.88 (s, 1H, C-4-H), 8.40 (m, 1H, C-7H).

2-Chloro-3-ethoxycarbonyl-1,8-naphthyridine (12): Yield: 76\%. Color: Pale yellow. M.p.: 96-98 ${ }^{\circ} \mathrm{C}$. FT-IR $\left(\mathrm{KBr}, \mathrm{v}, \mathrm{cm}^{-1}\right)$ : $3285(\mathrm{NH}), 3060$ (ArC-H), 1730 (C=0), 1595 (C=N), 760 (C-Cl). ${ }^{1} \mathrm{H}$ NMR (400 MHz, DMSO- $\left.d_{6}, \delta, \mathrm{ppm}\right): 1.48\left(\mathrm{~s}, 3 \mathrm{H}, \mathrm{CH}_{3}\right), 4.4(\mathrm{q}$, $\left.2 \mathrm{H}, \mathrm{OCH}_{2}\right), 7.28(\mathrm{t}, 1 \mathrm{H}, \mathrm{C}-6-\mathrm{H}), 7.46(\mathrm{~d}, 1 \mathrm{H}, \mathrm{C}-5-\mathrm{H}), 7.86(\mathrm{~s}, 1 \mathrm{H}, \mathrm{C}-$ $4-\mathrm{H}), 8.41(\mathrm{~m}, 1 \mathrm{H}, \mathrm{C}-7-\mathrm{H})$.

\subsection{Synthesis of 2-chloro-1,8-naphthyridine-3-hydrazide (13)}

To a solution of compound $\mathbf{1 1}$ (0.04 mole) in ethanol, hydrazine hydrate $(0.2$ mole) was added and the reaction mixture was stirred for $6 \mathrm{hr}$ in temperature below $100^{\circ} \mathrm{C}$. The solvent was evaporated to half under reduced pressure. The precipitate was cooled and collected by filtration then recrystallized from ethanol to give pure compound 13 (Scheme 3). Yield: $68 \%$. Color: Brown. M.p.: 256-257 ${ }^{\circ} \mathrm{C}$. FT-IR $(\mathrm{KBr}, v$, $\left.\mathrm{cm}^{-1}\right)$ : $3315(\mathrm{NH}), 3100(\mathrm{ArC}-\mathrm{H}), 1650(\mathrm{C}=0), 1585$ (C=N), 755 (C-Cl). ${ }^{1} \mathrm{H}$ NMR $\left(400 \mathrm{MHz}, \mathrm{DMSO}-d_{6}, \delta, \mathrm{ppm}\right): 5.25\left(\mathrm{~s}, 2 \mathrm{H}, \mathrm{NH}_{2}\right)$, 7.35 (t, 1H, C-6-H), 7.48 (d, 1H, C-5-H), 8.15 (s, 1H, C-4-H), 8.47 (m, 1H, C-7-H), $10.78(\mathrm{~s}, 1 \mathrm{H}, \mathrm{CO}-\mathrm{NH})$.

\subsection{Synthesis of 2[(2-chloro-1,8-naphthyridin-3-yl) carbonyl] hydrazine carbothioamide (14)}

A mixture of hydrazide (13) (0.02 mole) ammonium thiocyanate ( $4.56 \mathrm{~g}, 0.06$ mole), hydrochloric acid $(8 \mathrm{~mL})$ in absolute ethanol $(50 \mathrm{~mL})$ was refluxed for $20 \mathrm{hr}$. The solvent was evaporated under reduced pressure and the residue poured on crushed ice with stirring. The solid formed filtered and re-crystallized from ethanol to give pure compound $\mathbf{1 4}$ 
(Scheme 3). Yield: $55 \%$. Color: Brown. M.p.: $222-225^{\circ} \mathrm{C}$. FT-IR $\left(\mathrm{KBr}, v, \mathrm{~cm}^{-1}\right): 3385(\mathrm{NH}), 3035(\mathrm{ArC}-\mathrm{H}), 1660(\mathrm{C}=0), 1595$ $(\mathrm{C}=\mathrm{N}), 1225(\mathrm{C}=\mathrm{S}), 755$ (C-Cl). ${ }^{1} \mathrm{H}$ NMR $\left(400 \mathrm{MHz}, \mathrm{DMSO}-d_{6}, \delta\right.$, ppm): $5.20\left(\mathrm{~s}, 2 \mathrm{H}, \mathrm{NH}_{2}\right), 7.45$ (t, 1H, C-6-H), 7.78 (d, 1H, C-5-H), $7.83(\mathrm{~s}, 1 \mathrm{H}, \mathrm{C}-4-\mathrm{H}), 8.44(\mathrm{~m}, 1 \mathrm{H}, \mathrm{C}-7-\mathrm{H}), 9.52$ (s, 1H, NHCS), $10.78(\mathrm{~s}, 1 \mathrm{H}, \mathrm{CO}-\mathrm{NH})$.

\subsection{Synthesis of 5-(2-chloro-1,8-naphthyridin-3-yl)-4H- 1,2,4-triazole-3-thiol (15)}

To ethanolic solution of compound $\mathbf{1 4}$ (1.0 mmole), sodium hydroxide $(0.056 \mathrm{~g}, 1.0 \mathrm{mmole})$ in $5 \mathrm{~mL}$ water was added and stirred for $6 \mathrm{hr}$ at $\left(90{ }^{\circ} \mathrm{C}\right)$. The solution was filtered, the solution was then neutralized with dilute hydrochloric acid. The solid product was filtered off and crystallized from ethanol to give pure compound 15 (Scheme 3). Yield: 87\%. Color: Brown. M.p.: $225-227^{\circ} \mathrm{C}$. FT-IR (KBr, v, $\left.\mathrm{cm}^{-1}\right): 3350(\mathrm{NH}), 3038$ (ArC-H), 1605 (C=N), 1015 (C=S), $750(\mathrm{C}-\mathrm{Cl}) .{ }^{1} \mathrm{H}$ NMR (400 MHz, DMSO- $\left.d_{6}, \delta, p p m\right): 7.21(\mathrm{~s}, 1 \mathrm{H}, \mathrm{N}-\mathrm{H}), 7.45(\mathrm{t}, 1 \mathrm{H}, \mathrm{C}-6-\mathrm{H})$, 7.86 (d, 1H, C-5-H), 8.45 (s, 1H, C-4-H), 8.84 (m, 1H, C-7-H), $13.68(\mathrm{~s}, 1 \mathrm{H}, \mathrm{SH})$.

\subsection{Synthesis of 5-(2-chloro-1,8-naphthyridin-3-yl)-1,3,4- thiadiazol-2-amine (16)}

To a stirred solution of compound 14 (1.0mole) in (50 mL) ethanol, concentrated sulfuric acid $(6 \mathrm{~mL})$ was added and refluxed for $6 \mathrm{hr}$ at $\left(90^{\circ} \mathrm{C}\right)$. The solution was poured onto ice water, ammonia was added until basic, a precipitate was obtained which was filtered and crystallized from ethanol to give pure compound 16 (Scheme 3). Yield: 92\%. Color: Brown. M.p.: 202-205 ${ }^{\circ} \mathrm{C}$. FT-IR (KBr, v, cm-1): 3450 (NH), 3040 (ArCH), $1610(\mathrm{C}=\mathrm{N}), 765(\mathrm{C}-\mathrm{Cl}) .{ }^{1} \mathrm{H}$ NMR $\left(400 \mathrm{MHz}, \mathrm{DMSO}-d_{6}, \delta\right.$, ppm): 3.5 (s, 2H, NH 2$), 7.45$ (t, 1H, C-6-H), $7.85(\mathrm{~d}, 1 \mathrm{H}, \mathrm{C}-5-\mathrm{H})$, 8.45 (s, 1H, C-4-H), 8.85 (m, 1H, C-7-H)

\subsection{Synthesis of 5-(2-chloro-1,8-naphthyridin-3-yl)-1,3,4- oxadiazole-2(3H)-thione (17)}

To ethanolic solution of hydrazide (13) (1.0 mmole) potassium hydroxide $(0.056 \mathrm{~g}, 1.0 \mathrm{mmole})$ and carbon disulfide ( 2 mmole) was added. The mixture was heated under reflux until the hydrogen sulfide evolution ceased. The solvent was then removed, water added and the solution was filtered off. The filtrate was acidified with diluted hydrochloride acid. The precipitate formed was collected washed with water and crystallized from ethanol to give pure compound 17 (Scheme 3). Yield: $90 \%$. Color: Yellow. M.p.: $196-198{ }^{\circ} \mathrm{C}$. FT-IR (KBr, v, $\left.\mathrm{cm}^{-1}\right)$ : 3382, $3220(\mathrm{NH}), 3050(\mathrm{ArC}-\mathrm{H}), 1605(\mathrm{C}=\mathrm{N}), 1050(\mathrm{C}=\mathrm{S})$, 755 (C-Cl). ${ }^{1} \mathrm{H}$ NMR (400 MHz, DMSO- $\left.d_{6}, \delta, \mathrm{ppm}\right): 7.40$ (t, $1 \mathrm{H}, \mathrm{C}-$ 6-H), $7.6(\mathrm{~s}, 1 \mathrm{H}, \mathrm{NH}), 7.80(\mathrm{~d}, 1 \mathrm{H}, \mathrm{C}-5-\mathrm{H}), 8.40(\mathrm{~s}, 1 \mathrm{H}, \mathrm{C}-4-\mathrm{H})$, $8.82(\mathrm{~m}, 1 \mathrm{H}, \mathrm{C}-7-\mathrm{H})$.

\section{Result and discussion}

\subsection{Synthesis}

The starting material 2-chloro-3-formyl-1,8-naphthyridine (1) was synthesized by the reaction of $N$-(pyridine-2-yl) acetamide with $\mathrm{DMF}-\mathrm{POCl}_{3}$ at $80-90{ }^{\circ} \mathrm{C}$. The Vilsmeier cyclization of $\mathrm{N}$-(pyridine-2-yl)acetamide was carried out by adding $\mathrm{POCl}_{3}$ to substrate in DMF at $0-5{ }^{\circ} \mathrm{C}$ followed by heating to $90^{\circ} \mathrm{C}[21]$ (Scheme 1)

The structure of compound 1 could be matched with their spectral data. The IR spectrum of compound 1 showed a band for carbonyl group at $1720 \mathrm{~cm}^{-1}$ and band at $2780 \mathrm{~cm}^{-1}$ for $v \mathrm{CH}$, and the ${ }^{1} \mathrm{H}$ NMR spectrum indicated the presence of aldehyde proton at $\delta 9.85 \mathrm{ppm}$.

Treatment of compound 1 with sodium sulphide afford 2mercapto-3-formyl-1,8-naphthyridine (2) [22] (Scheme 2). The IR spectra showed a sharp and strong absorption at $1690 \mathrm{~cm}^{-1}$ for carbonyl group and strong absorption at $1050 \mathrm{~cm}^{-1}$ for $\mathrm{C}=\mathrm{S}$ and absence of absorption $775 \mathrm{~cm}^{-1}$ for $\mathrm{C}-\mathrm{Cl}$. The ${ }^{1} \mathrm{H}$ NMR spectrum indicated the presence of aldehydic proton at $\delta 9.88$ ppm.

The reaction of compound $\mathbf{1}$ with $\mathrm{Na}_{2} \mathrm{~S} / \mathrm{DMF}$ followed by reaction with alkyl halide afforded thioethers 3 and 4 . The ${ }^{1} \mathrm{H}$ NMR spectra of compound 3 shows a singlet at $\delta 2.86 \mathrm{ppm}$ for $\mathrm{S}-\mathrm{CH}_{3}$, and compound 4 shows singlet at $\delta 4.6 \mathrm{ppm}$ for $\mathrm{S}-\mathrm{CH}_{2}-$ and multiplets at $\delta$ 7.1-7.4 ppm for Ar-H.

To prepare Schiff base (5, 6 and 7), the compound 1 was treated with phenyl hydrazine or substituted phenyl hydrazine. The IR spectrum of compounds showed the absence of absorption at $1720 \mathrm{~cm}^{-1}$ for $\mathrm{vC}=0$ and showed absorption between 3340,3335 and $3324 \mathrm{~cm}^{-1}$ for $\mathrm{NH}$ groups, respectively. The ${ }^{1} \mathrm{H}$ NMR spectrum of compounds $(5,6$ and 7$)$ exhibited no peak corresponding to aldehydic proton instead it shows signals at $\delta 7.3,6.2$ and $7.2 \mathrm{ppm}$ for $\mathrm{NH}$, respectively.

The substituted Schiff base (5, 6 and 7) was also reacted with chloro acetyl chloride in the presence of triethylamine to give azetidin-2-one derivatives $(\mathbf{8}, \mathbf{9}$ and $\mathbf{1 0})$. The formation of compounds were supported spectroscopically by showing the absence of $\mathrm{CH}=\mathrm{N}$ proton at $\delta 9.02-9.14 \mathrm{ppm}$ in the ${ }^{1} \mathrm{H}$ NMR spectra and presence of strong absorption at $1665 \mathrm{~cm}^{-1}$ in the IR for $v \mathrm{C}=0$ in the azetidine rings.

The formyl group in 1,8-naphthyridine (1) was oxidized to esters (11 and 12) in good yield by using NIS- $\mathrm{K}_{2} \mathrm{CO}_{3}$ in $\mathrm{CH}_{3} \mathrm{OH} / \mathrm{C}_{2} \mathrm{H}_{5} \mathrm{OH}$ at room temperature (Scheme 3). The IR spectrum of compounds $\mathbf{1 1}$ and $\mathbf{1 2}$ showed a sharp strong absorption at 1735 and $1730 \mathrm{~cm}^{-1}$ due to the presence of ester function in the structures, respectively. The ${ }^{1} \mathrm{H}$ NMR spectra substantiated the results of the IR analysis. The characteristic signals of an ester moiety confirm the presence of an ester group in the structure as singlet at $\delta 4.15 \mathrm{ppm}$ for $0-\mathrm{CH}_{3}$ for compound 11 and as quartet and triplet for $\mathrm{CH}_{2}$ and $\mathrm{CH}_{3}$ at $\delta$ 4.4 and $1.48 \mathrm{ppm}$, respectively, for compound $\mathbf{1 2}$.

Then compound $\mathbf{1 1}$ was reacted with hydrazine hydrate in ethanol at reflux temperature to obtain 2-chloro-1,8naphthyridine-3-hydrazide. The IR spectrum of compound 13 showed the absence of ester stretching frequency instead it gave a band at $1650 \mathrm{~cm}^{-1}$ for carbonyl group and band at 3315 $\mathrm{cm}^{-1}$ for NH group. ${ }^{1} \mathrm{H}$ NMR spectrum of compound 13 exhibited no peak corresponding to ester instead it shows signals at $\delta 10.78 \mathrm{ppm}$ and at $\delta 5.25 \mathrm{ppm}$ for $\mathrm{CONH}$ and $\mathrm{NH}_{2}$ of hydrazide, respectively.

Thiosemicarbazide (14) was synthesized from reaction of compound 13 with ammonium thiocyanate. The ${ }^{1} \mathrm{H}$ NMR showed two characteristic singlet for CSNH and CONH at $\delta 9.52$ and $10.78 \mathrm{ppm}$, respectively. The IR spectrum supported these results and showed band at 1660 and $1225 \mathrm{~cm}^{-1}$ for $\mathrm{C}=0$ and $\mathrm{C}=\mathrm{S}$ group, respectively.

Compound 15 and 16 was synthesized from the cyclization of thiosemicarbazide (14) in basic and acidic medium. The ${ }^{1} \mathrm{H}$ NMR is characterized by the disappearance of thiosemicarbazide signals.

The reaction of compound $\mathbf{3}$ with carbon disulfide in alcoholic potassium hydroxide affords oxadiazolo (17) (Scheme 3).

\subsection{Biological studies}

The biological studies of compounds $(\mathbf{1 5}, \mathbf{1 6}$ and 17) were assayed for antibacterial activity against two representative Gram-positive organisms such as Staphylococcus aureus, Staphylococcus epidermidis and two Gram-negative organism such as Escherichia coli and Proteus vulgaris by broth dilution method. Ciprofloxacin was used as standard for comparison of antibacterial activities. Inhibition was recorded by measuring the diameter of the inhibition zone at the end of $24 \mathrm{hr}$ at $35^{\circ} \mathrm{C}$.

The results showed that these compounds $(15,16$ and 17) have a good activity against (Staphylococcus aureus and Staphylococcus epidermidis) Table 1. 
Table 1. Antibacterial activity data of compound 15, 16, and 17.

\begin{tabular}{|c|c|c|c|c|c|}
\hline & \multicolumn{4}{|l|}{ Zone of inhibition in $\mathrm{mm}$} \\
\hline \multicolumn{2}{|c|}{ Compound } & $\begin{array}{l}\text { Staphylococcus aureus } \\
10 \mathrm{mg} / \text { disk }\end{array}$ & $\begin{array}{l}\text { Staphylococcus epidermidis } \\
10 \mathrm{mg} / \text { disk }\end{array}$ & $\begin{array}{l}\text { Escherichia coli } \\
10 \mathrm{mg} / \text { disk }\end{array}$ & $\begin{array}{l}\text { Proteus vulgaris } \\
10 \mathrm{mg} / \text { disk } \\
\end{array}$ \\
\hline$\overline{15}$ & & 26 & 24 & 12 & 10 \\
\hline 16 & & 23 & 22 & 11 & 10 \\
\hline 17 & & 18 & 22 & 13 & 10 \\
\hline \multirow[t]{2}{*}{ Control } & Ciprofloxacin, $5 \mathrm{mg} /$ disk & - & - & 15 & 14 \\
\hline & Chloramphenicol, $30 \mathrm{mg} /$ disk & 17 & 16 & 14 & - \\
\hline
\end{tabular}

\section{Conclusion}

In conclusion, we have developed a simple and efficient method for the synthesis of some new 1,8-naphthyridine derivatives and characterized by spectral studies. The newly synthesized compounds $(\mathbf{1 5}, 16$ and 17) were evaluated for antibacterial activities. The results obtained indicated that these compounds have a good activity against (Staphylococcus aureus and Staphylococcus epidermidis).

\section{Acknowledgement}

The authors are thankful to Head, Department of Chemistry, Eskisehir Osmangazi University, Eskisehir, Turkey for providing ${ }^{1} \mathrm{H}$ NMR spectroscopy. We are also thankful to Head, Department of Biology, Mosul University for providing laboratory facilities.

\section{References}

[1]. Marchese, A.; Debbia, E. A.; Schito, G. C. J. Antimicrob. Chemother. 2000, 46(Suppl 3), 11-15.

[2]. Ferrarini, P. L.; Mori, C.; Tellini. F. N. Ed. Sci. 1990, 45, 385-389.

[3]. Lirvinov, V. P. Adv. Heterocyclic. Chem. 2006, 91, 222-227.

[4]. Supuran, C. T.; Scozzafava, A. Expert Opin. Ther. Pat. 2004, 14, 35-53.

[5]. Cooper, C. S.; Klock, P. L.; Chu, D. T. W.; Hardy, D. J.; Swanson, R. N. J. Med. Chem. 1992, 35, 1392-1398.

[6]. Balin, G. B.; Tan, W. L. Aust. J. Chem. 1984, 37, 1065-1073.

[7]. Chen, K.; Hsiech, M.; Anthony, K. J. Med. Chem. 1997, 40, 3049-3056.

[8]. Gorechi, D. K. J.; Hawes, E. M. J. Med. Chem. 1973, 20, 124-128.

[9]. Ferrarini, P. L.; Mori, C.; Badawenh, M.; Calderone, V. Eur. J. Med. Chem. 1998, 33, 3383-3397.

[10]. Nyce, P. L.; Steinman, M. Synthesis 1991, 571-574

[11]. Santilli, A. A.; Scotese, A. C.; Baher, R. F.; Bell, S. C. J. Med. Chem. 1987, 30, 2270-2277.

[12]. Ferrarini, P. L.; Mori, C.; Primofiore, G.; Gazlolari, L. J. Heterocycl. Chem. 1990, 27, 881-886.

[13]. Reddy, K. R.; Vijayender, M. K.; Sreenivasulu, B. J. Indian Chem. Soc. 1986, 63, 443-446.

[14]. Reddy, K. R.; Mogilaiah, K.; Sreenivasulu, B. Indian J. Chem. B 1989, 28, 362-364.

[15]. Rao, G. R.; Mogilaiah, K.; Reddy, K. R.; Sreenivasulu, B. J. Indian Chem. Soc. B. 1987, 64, 710-718.

[16]. Bartuman, W., Konz, E.; Ruger, W. Synthesis 1988, 9, 680-683.

[17]. Vilsmeier, A.; Haack, A. Chem. Ber. B 1927, 60, 119-122.

[18]. Fujisawa, T.; Lida, S.; Sato, T. Chem. Lett. 1984, 1173-1176.

[19]. Venugopal, M.; Perumal, P. T.; Rajadurai, S. Tetrahedron Lett. 1974, 15, 913-916.

[20]. Rao, M. S. C.; Rao, G. C. K. Indian J. Chem. B 1988, 27, 213-217.

[21]. Kumar, V.; Jaggi, M.; Singh, A. T.; Madoan, A.; Sanna, V.; Singh, P.; Sharma, P. K.; Irrchnaiya, R.; Burman, A. C. Eur. J. Med. Chem. 2009, 44, 3356-3362.

[22]. Meth-Cohu, O.; Platt, L.; Kerry, M. A.; Boyd, G. W.; Mackay. P. S. J. Chem. Soc., Perkin Trans I 1999, 2315-2318. 